\title{
GERMINAÇĀO DAS SEMENTES DE MARMELO: MEIOS E PERÍODOS DE ESTRATIFICAÇÃO E PROCESSOS DE PREPARO (1)
}

\author{
FERNANDO ANTONIO CAMPO-DALL'ORTO $(2,7)$ \\ MÁRIO OJIMA $\left({ }^{2}\right)$, \\ EPAMINONDAS SANSIGOLO DE BARROS FERRAZ $\left({ }^{3}\right)$, \\ TOSHIO IGUE $\left(^{4}\right)$, FERNANDO PICARELLI MARTINS $\left({ }^{5,7}\right)$ \\ O ORLANDO RIGITANO $\left.{ }^{6}\right)$
}

\begin{abstract}
RESUMO
Dois experimentos foram conduzidos no sentido de se obter maior conhecimento das sementes de marmelo, como subsídios essenciais ao meIhoramento genético dessa frutifera e à obtenção de porta-enxertos de pés francos para a pereira, a nespereira e o próprio marmeleiro. Os aspectos focalizados $e$ as respostas obtidas foram: (a) Meios e periodos de estratificaçāo. A estratificação úmida, a baixa temperatura $\left(5\right.$ a $\left.10^{\circ} \mathrm{C}\right)$ foi indispensável à quebra de dormência das variedades pesquisadas, Portugal e Smyrna. As sementes da primeira apresentaram menor exigência de frio, para quebra da sua dormência fisiológica. Os três meios de estratificaçāo adotados - algodão, areia e lavagem - propiciaram condições satisfatórias e teores adequados de umidade às sementes: a areia se constituiu no mais homogêneo; o algodăo, no mais asséptico e o processo por lavagem, o de
\end{abstract}

(1) Parte da Dissertação apresentada pelo primeiro autor à Escola Superior de Agricultura "Luiz de Queiroz", da Universidade de São Paulo. Área de concentração: "Energia Nuclear na Agricultura". Recebido para publicaçẩo em 28 de novembro de 1986.

(2) Seção de Fruticultura de Clima Temperado, Instituto Agronómico (IAC), Caixa Postal 28, 13.001 Campinas (SP). (SP).

(3) Seção de Instrumentaçăo e Controle, Centro de Energia Nuciear na Agricultura (CENA), Piracicaba

( $\left.{ }^{4}\right)$ Seção de Técnica Experimental e Cálculo (IAC).

(5) Estaçăo Experimental de Jundial (IAC).

( ${ }^{6}$ Consultor Científico, Pesquisador aposentado (IAC).

(7) Com bolsa de pesquisa do CNPq. 
execução mais trabaihosa. (b) Processos de preparo na viabilidade das sementes. Com base nos dados de germinação ainda no frigorífico e de emergência de plântulas nos canteiros, procurou-se averiguar o melhor procedimento de preparo das sementes, sem comprometimento acentuado da sua viabilidade. Constatou-se que a demora na extração das sementes dos frutos, mantidos no ambiente até 90 dias, e a falta de estratificação a frio úmido, resultaram em baixas porcentagens de germinação ou de emergência; a viabilidade das sementes diminuiu rapidamente à medida que a polpa dos frutos, a mucilagem pectinosa e o "cuore" se deterioraram.

Termos de indexaçäo: marmelo, Cydonia oblonga Mill., sementes, meios e periodos de estratificaçâo, preparo; germinação, emergência, viabilidade.

\section{INTRODUÇÃO}

O marmeleiro vinha sendo cultivado em diversas áreas do País, desde o início do período colonial, com produções exuberantes e, seus frutos, comercializados em profusão, até os primeiros decênios deste século. Nessa época, todavia, a entomosporiose passou a constituir sério problema à cultura (CAMARGO \& GONÇALVES, 1943). Essa doença, causada pelo fungo Entomosporium maculatum Lèv., também conhecida pelas denominações comuns de "requeima", "mela" ou "crestamento" da folha do marmeleiro, apesar de incidir igualmente em seus ramos verdes e frutos, dizimou os marmeleirais existentes, e as produções dessa fruta se tornaram cada vez menores.

A diminuição da oferta dessa matéria-prima e sua conseqüente valorização vem sendo sentida pelas fábricas de conserva, que a têm importado sob a forma de polpa da Argentina, ou a têm substituído parcialmente pela mistura com a de maçã ou laranja, encontradas em maior abundância.

Esses fatores fizeram com que surgisse, novamente, estímulo gradual para a produção comercial de marmelo. Pode-se dizer que a cultura do marmeleiro se encontra, hoje, em fase de transiçāo, ou seja, existe uma forte tendência em sair do ponto de estagnação em que se encontra, com a implantação de novos e mais produtivos marmeleirais.

Desse modo, é de retevante interesse o desenvolvimento dos trabathos de melhoramento genético do marmeleiro, visando à obtenção e seleçāo de novas variedades ou à definição das melhores introduções, como a 'Provence' e 'M.INTA-37', com características agronômicas superiores de adaptabilidade, produção, precocidade de colheitas iniciais, rusticidade (a exemplo da maior resistência à incidência do fungo causador da entomosporiose), além da qualidade dos frutos, para as diferentes finalidades, ou seja, indústria e mesa (DALL'ORTO et al. 1985a, 1987). 
Nos casos particulares de pereiras, e mesmo nespereiras, observam-se, nas plantas, efeitos marcantes de ananismo quando enxertadas sobre marmeleiros. Desse modo, porta-enxertos de clones selecionados de marmeleiro podem substituir, com vantagens, aqueles obtidos de pés francos das duas espécies referidas: permitem maior densidade de plantas, precocidade na produção e facilidade nos tratos culturais. Essa técnica, ao propiciar maior produtividade em plantas jovens, resulta no aumento da rentabilidade dos pomares.

Nesse particular, salienta-se, dentro do programa de melhoramento genético do marmeleiro, a importância da obtenção de material clonal para porta-enxerto daquelas frutíferas, que, dentre outras qualidades agronômicas, se destaque pela facilidade de enraizamento, tanto pelo processo de simples estaquia como por "amontoa-de-cepa". No tocante ainda aos porta-enxertos, é desejável efetuar investigações acerca da viabilidade de utilização de pés francos do próprio marmeleiro, tendo em vista a relativa facilidade na obtençāo de sementes.

Os trabalhos assim preconizados para o marmeleiro requerem primordialmente a utilização de sementes em sua propagação. A literatura pertinente ao assunto é bastante escassa.

A realização de pesquisas sobre a propagação seminifera do marmeleiro constitui importante ponto de partida para colher as informações básicas e indispensáveis ao seu programa de melhoramento genético (DALL'ORTO, 1982; DALL'ORTO et al., 1985b).

\section{MATERIAL E MÉTODOS}

\subsection{Meios e períodos de estratificação}

Colheram-se, em fevereiro de 1976, frutos maduros e sadios de duas variedades de marmeleiro - Portugal e Smyrna - constantes do ensaio de poda e de competição de variedades, na Estação Experimental de Jundiaí, do Instituto Agronômico. Em 13/2/1976, depois de escolhidos cem frutos uniformes por variedade, efetuou-se cuidadosa extração e lavagem das sementes; estas, a seguir, foram secas à sombra, sobre sacos de papel, em ambiente de laboratório.

Em 25/2/76, quando todo o material se encontrava preparado, selecionaram-se 2.000 sementes por variedade, separando-as em 40 parcelas de 50 sementes. Destinaram-se quatro parcelas, por variedade, a cada um dos seguintes tratamentos:

1) semeadura imediata, sem estratificação a frio úmido;

2,3 e 4) estratificação das sementes a frio, em algodão umedecido, por um, dois e três meses respectivamente. 
5,6 e 7) estratificação a frio, em areia úmida, por um, dois e três meses respectivamente.

8, 9 e 10) estratificação a frio, em placas de Petri, sem substrato, através de uma a duas lavagens semanais das sementes, por um, dois e três meses respectivamente (Figura 1).

As sementes pertencentes ao tratamento 1 foram semeadas em 26/2, após hidratadas por 24 horas, e tratadas com solução fungicida - Thiran a $2 \%$. Procedeu-se à semeadura sob o ripado, a $50 \%$ de luminosidade, em canteiros de terra do mato previamente tratada, mediante três irrigações com solução de zineb a $0,5 \%$. As demais, de acordo com a especificação dos tratamentos, foram estratificadas em placas de Petri, colocando-se em cada uma 50 sementes referentes a cada parcela experimental e mantendo-as fechadas em câmara frigorífica a 5$10^{\circ} \mathrm{C}$. Antes da estratificação, essas sementes foram também imersas em água, por 24 horas e, em seguida, tratadas com solução de Thiran a $2 \%$.

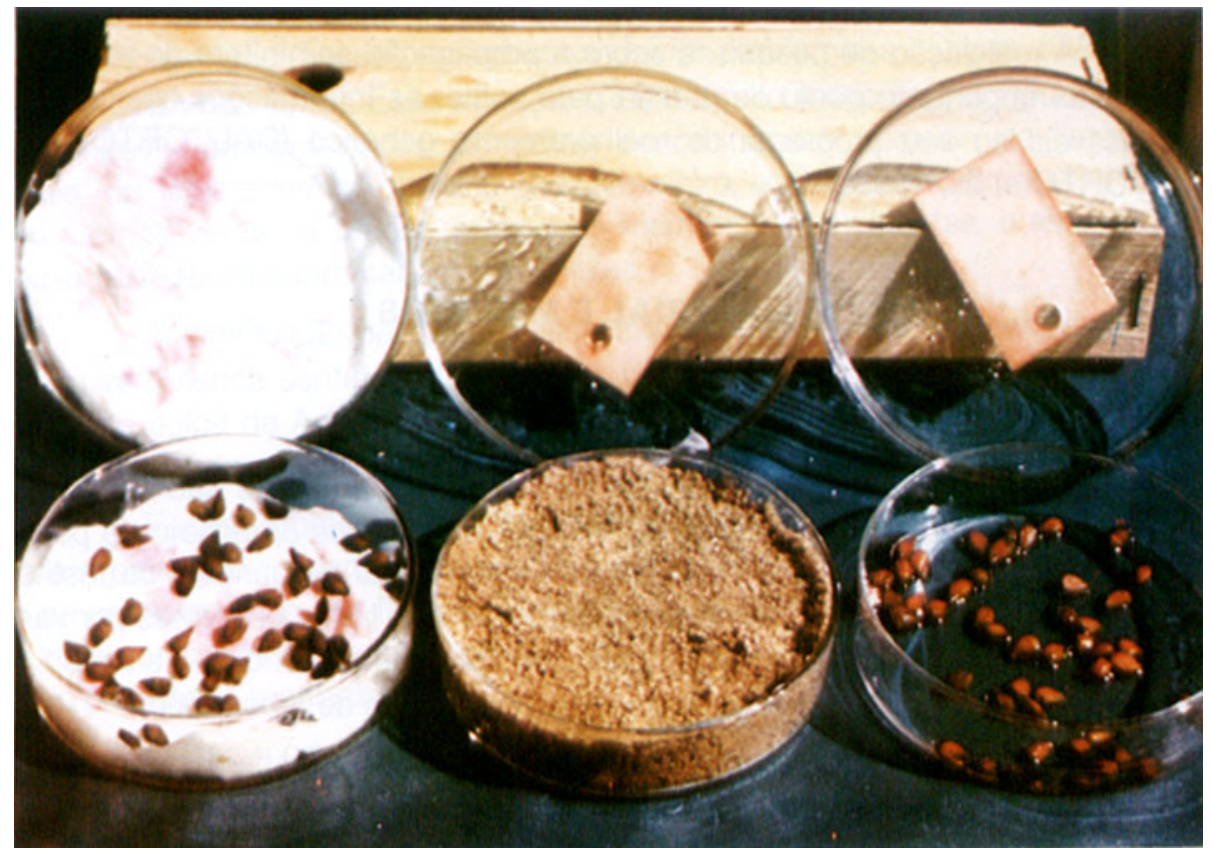

FIGURA 1. Meios de estratificação a frio úmido das sementes de marmelo; da esquerda para a direita: algodão, areia e o processo "por lavagem". 
Em 26/3, 26/4 e 26/5/76, respectivamente, ao término do primeiro, segundo e terceiro periodo estabelecido, efetuaram-se as semeaduras relativas aos tratamentos de estratificação, em parcelas individualizadas, sob o ripado, em canteiros de terra, preparados conforme já descrito. Ao final do último periodo, efetuou-se o primeiro protocolo dos resultados de germinação, ainda no frigorífico e, em seguida, a semeadura de todo o material germinado e por germinar.

A semeadura foi feita a cerca de $1 \mathrm{~cm}$ de profundidade, adotando-se a distância de $20 \mathrm{~cm}$ entre as linhas e de $2 \mathrm{~cm}$ entre as sementes, seguindo 0 delineamento experimental de blocos ao acaso. Foram feitas regas, no sentido de manter o canteiro sempre úmido, e pulverizações semanais das plântulas emergentes, com os fungicidas maneb e zineb a $0,3 \%$, e os inseticidas paratiom metilico e demetom metílico a $0,15 \%$.

Em 26/7/76, transcorridos dois meses da última semeadura, fez-se a leitura final da emergência das plântulas, que vinha sendo anotada quinzenalmente.

\subsection{Processos de preparo das sementes}

Visando ao estudo de processos de preparo das sementes de marmelo e da influência na sua viabilidade, colheram-se, em 20/2/1976, frutos maduros, uniformes e sadios de marmeleiros da variedade Portugal, em propriedade particular, localizáda no Bairro Helvetia, em Campinas.

Adotaram-se os seguintes tratamentos: tratificação;

1) extração imediata das sementes e semeadura logo a seguir, sem esfrio úmido;

2) extração imediata das sementes e semeadura após estratificação a

$3,4,5,6$ e 7) extraçáo das sementes de frutos mantidos em ambiente de laboratório por $15,30,45,60$ e 90 dias respectivamente, e semeadura após estratificação a frio úmido;

8,9 e 10) extração das sementes de frutos conservados no frigorífico, a $5-10^{\circ} \mathrm{C}$, por 30,60 e 90 dias respectivamente, e semeadura imediata sem estratificaçāo;

11,12 e 13) extração das sementes de frutos conservados no frigorifico por 30,60 e 90 dias respectivamente, e semeadura após estratificação a frio úmido;

$14,15,16$ e 17) extração das sementes mantidas envoltas pela mucilagem, ainda nos respectivos "cuores" $\left.{ }^{8}\right)$, por 7, 15, 22 e 30 dias, respectivamente, e semeadura após estratificação a frio úmido;

${ }^{(8)}$ Italianismo, de "cucre" (coração), que bem define o receptáculo das sementes em suas lojas, nos frutos do tipo pomo. 
$18,19,20$ e 21) extração das sementes conservadas envoltas pela mucilagem ainda nos "cuores" e imersas em água, por 7, 15, 22 e 30 dias respectivamente, e semeadura após estratificação a frio úmido.

O delineamento do ensaio, nos canteiros de semeadura, foi o de blocos ao acaso, com 21 tratamentos e quatro repetições. Nesse experimento, iniciado em 26/2/1976, utilizaram-se 40 frutos por tratamento, divididos em quatro lotes de dez. Nos tratamentos de números 3 a 13, cada lote foi colocado separadamente em recipientes de plástico, mantidos abertos, durante o período de conservação. Nos tratamentos 14 e 21, partiram-se os frutos, e apenas as sementes, ainda envoltas pela mucilagem nos respectivos "cuores", foram mantidas em béqueres grandes, semicobertos.

De acordo com a especificação de cada tratamento, as sementes foram extraídas, lavadas em água corrente, postas a secar sobre papel, à sombra, e a seguir conservadas em sacos de papel-manteiga, até a estratificação, realizada em 17/6/76. Nos tratamentos 1, 8, 9 e 10, as sementes extraídas e lavadas foram deixadas imersas em água por 24 horas e, em seguida, tratadas com solução de Thiran a $2 \%$ e semeadas. A semeadura se efetuou, para esses tratamentos, 24 horas depois da extração das sementes.

Para a estratificação, utilizaram-se, por tratamento, quatro placas de Petri, colocando-se, em cada uma, 50 sementes referentes à parcela experimental, tendo areia grossa umedecida como substrato e mantendo-as fechadas em câmara frigorífica a $5-10^{\circ} \mathrm{C}$. Antes da estratificação, as sementes foram também imersas em água por 24 horas e então tratadas com solução de Thiran a $2 \%$.

Em 31/8/76, depois de 75 dias de estratificação, fez-se o primeiro protocolo dos resultados de germinação, ainda no frigorífico, procedendo-se, em seguida, à semeadura de todo o material germinado e por germinar.

Para todos os tratamentos, a semeadura se fez em canteiros de terra, previamente tratados com pastilhas de fosfina, sob ripado, a $50 \%$ de luminosidade.

Em 1\%/11/76, decorridos dois meses da semeadura, efetuou-se a leitura final da emergência das plântulas, que vinha sendo anotada quinzenalmente.

\section{RESULTADOS E DISCUSSÃO}

\subsection{Meios e periodos de estratificação}

No quadro 1, acham-se as porcentagens médias de emergência das plântulas de marmelo, obtidas em canteiros de terra, sob ripado, a partir das sementes das duas variedades estudadas - Portugal e Smyrna - correspon- 
dentes aos tratamentos sem estratificaçāo e com estratificação úmida e à baixa temperatura $\left(5 \mathrm{a} 10^{\circ} \mathrm{C}\right)$, por três periodos e em três diferentes meios. No que concerne à estratificação das sementes por três meses, acham-se também os resultados parciais de germinação, verificados nas placas de Petri, ainda no írigorífico, antes da semeadura nos canteiros. São ainda mostrados os dados de porcentagem transformados em arco seno $\sqrt{\mathrm{P} / 100}$, com as letras indicativas de classe estatística, pelo teste de Tukey, ao nivel de $5 \%$. No quadro 2, que complementa o anterior, é apresentada a análise da emergência média conjunta, das duas variedades de marmelo estudadas.

A germinação das sementes iniciou-se aos 68 dias de estratificação a frio úmido, ainda no frigorifico, e com maior intensidade na variedade Portugal, que denotou, portanto, maior velocidade na quebra de sua dormência. A emergência inicial das plântulas, nos canteiros de terra, ocorreu cerca de dez dias após a semeadura, nos tratamentos de estratificação por um mês, e oito dias após, naqueles de dois meses.

Os dados do quadro 1 mostram que a variedade Portugal comportou-se de modo nitidamente superior à Smyrna, em relaçāo à emergência das plântulas, tanto na estratificação das sementes por um mês, nos três diferentes meios, quanto na estratificação por dois meses, no substrato de areia e no procedimento por "lavagem". Entretanto, no terceiro mês de estratificação, as porcentagens finais de emergência se equivaleram. As sementes da variedade Portugal, desse modo, apresentaram menor exigência de frio para eliminaçáo de sua dormência fisiológica.

Os resultados desse experimento confirmam a hipótese de que o processo de estratificação a frio úmido é indispensável à quebra de dormência das sementes de marmeleiro. Com efeito, sem esse processo, a emergência das plântulas foi praticamente nula; a estratificação por um mês mostrou-se insuficiente, com índices ainda baixos de emergência. Além disso, nas plantas dos canteiros de semeadura correspondentes principalmente ao primeiro periodo de estratificação, observaram-se condições de ananismo - internódios curtos, presença de rosetas e de pequenos tufos de folhas arredondadas nos ápices das plântulas, além de outros sintomas de desenvolvimento anormal, ou seja, caulículos finos, plântulas irregulares, de pequeno vigor e de crescimento desuniforme e lento.

Nas duas variedades, quando adotado o substrato de algodâo ou o processo de "lavagem", o periodo mínimo de estratificação situou-se em torno de três meses, enquanto no substrato de areia esse período foi abreviado para dois meses, especialmente para 'Portugal'. A metodologia de "lavagem" das sementes mostrou-se inferior em confronto com os outros dois procedimentos, principalmente em relação à variedade Smyrna, no período de dois meses de estratificação. Entretanto, a emergência média conjunta das duas variedades, mostrada pelo quadro 2, ressalta que o periodo de três meses de estratificaçāo foi superior ao de dois meses e este, melhor que o de um mês. 


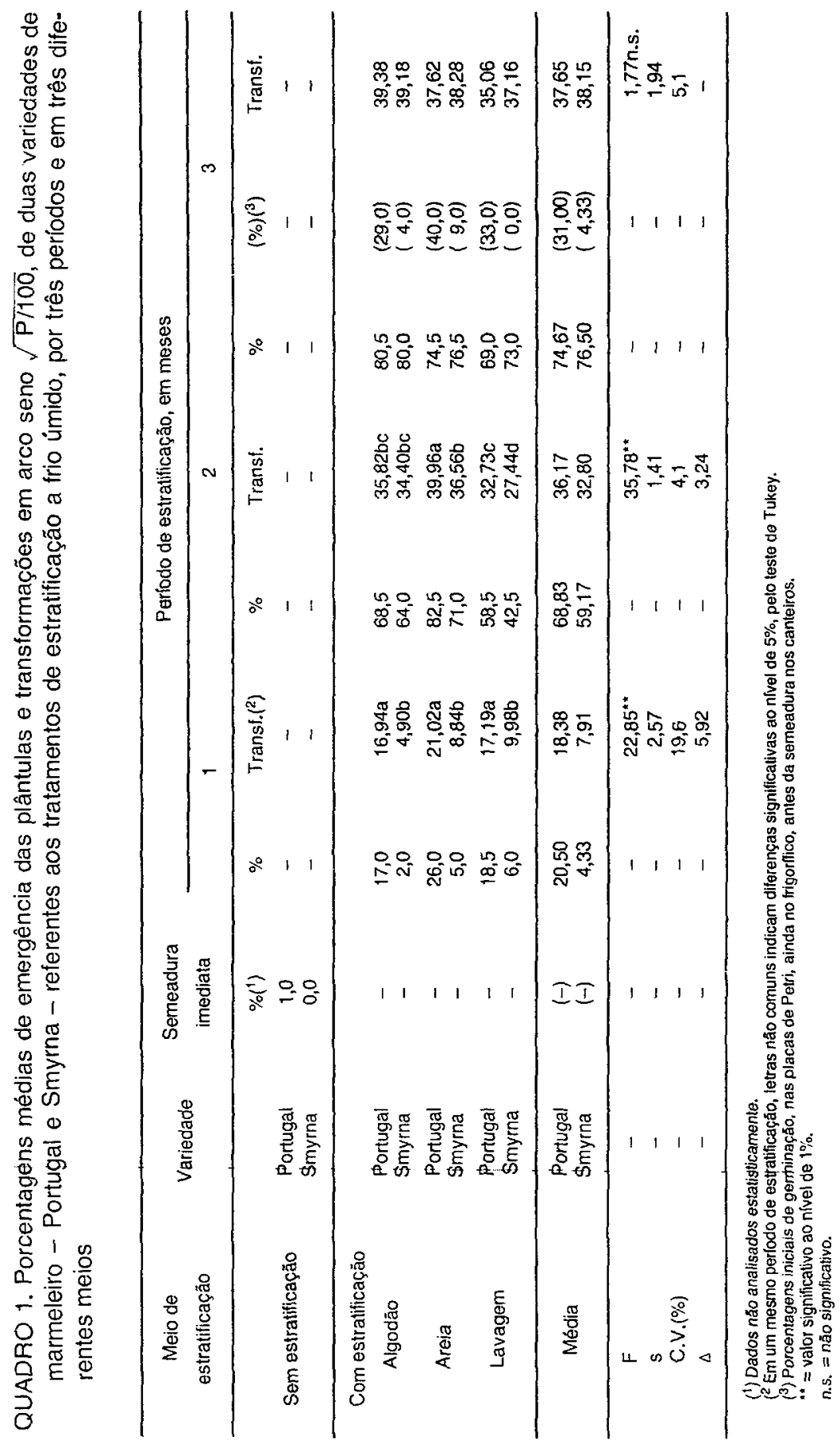


QUADRO 2. Análise de emergência média conjunta de plântulas de marmelo das variedades Portugal e Smyrna, com base nos dados transformados em arco seno $\sqrt{P / 100}$

\begin{tabular}{|c|c|c|c|c|}
\hline \multicolumn{5}{|c|}{ Períodos de estratificação, em meses } \\
\hline Meio de & 1 & 2 & 3 & Média geral \\
\hline Estratificaçāo & $\Delta=3,34\left({ }^{1}\right)$ & $\Delta=1,83$ & $\Delta=2,51$ & $\Delta=1,43$ \\
\hline Algodão & $10,92 b$ & $35,11 b$ & 39,28 a & $28,44 b$ \\
\hline Areia & $14,93 a$ & 38,26 a & $37,91 a b$ & $30,37 \mathrm{a}$ \\
\hline Lavagem & $13,58 \mathrm{ab}$ & $30,09 \mathrm{c}$ & $36,56 b$ & $26,74 \mathrm{c}$ \\
\hline \multicolumn{5}{|l|}{ Média gera! } \\
\hline$\Delta=1,43$ & $13,15 \mathrm{C}$ & $34,49 \mathrm{~B}$ & $37,92 \mathrm{~A}$ & 28,52 \\
\hline
\end{tabular}

(1)Diferença significativa: dentro de um mesmo período de estratificação, entre médias gerais de períodos e entre médias gerais de meios de estratificação, letras não comuns indicam diferenças significativas pelo teste de Tukey a $5 \%$.

Ao final da experimentação, e mesmo em seu transcorrer, verificou-se que as falhas constatadas nos leitos de semeadura eram devidas às três seguintes causas: (a) morte das plântulas por incidência de fungos causadores de "tombamento" em pós-emergência; (b) deterioração das sementes por ação de microorganismos saprófitos, notada especialmente nos tratamentos que envolveram o processo de estratificaçāo por "lavagem"; e (c) sementes permanecidas "duras", sem condiçōes de pronta germinação, encontradas com maior freqüência naquelas não estratificadas ou submetidas a. períodos insuficientes de estratificação (um ou dois meses).

Os três meios de estratificação propiciaram teores adequados de umidade e apresentaram condiçōes satisfatórias à quebra de dormência das sementes. Todavia, o substrato de algodáo constituiu-se no mais asséptico; o de areia, no mais hornogêneo e o de melhor equilibrio d'água, sendo, portanto, o mais eficiente. O processo de estratificação por "lavagem" foi o mais trabalhoso e menos eficaz.

Em termos de viabilidade de aplicação, o meio de algodão mostrou ser o de maior utilidade à experimentação, com perdas reduzidas de sementes, por contaminação fúngica ou bacteriana. O substrato de areia salientou-se como o mais adequado à realização da estratificação de maiores quantidades de sementes, porém, quanto à finalidade experimental, perdeu em precisão por dificultar a observação individual das sementes. O processo de estratificação por lavagem caracterizou-se como o de execução mais trabaihosa, pois exigiu acompanhamento sistemático, pela necessidade de umedecimento ou lavagem das semen- 
tes a cada três ou cinco dias, durante todo o transcorrer do período. Evidenciou-se pouco prático para um número mais elevado de sementes e apresentou problema mais sério de deterioração de sementes.

\subsection{Processos de preparo das sementes}

No quadro 3, encontram-se os resultados médios em porcentagem, relativos aos protocolos: inicial de germinação das sementes no frigorifico, e final, de emergência das plântulas nos canteiros, bem como os dados de emergência transformados em arco seno $\sqrt{\mathrm{P} / 100}$, dos 21 processos de preparo de sementes. Junto aos dados transformados, encontram-se as letras indicativas de classe estatística, pelo teste de Tukey, ao nivel de $5 \%$.

Esses dados evidenciam substanciais diferenças na germinação das sementes e na emergência das plântulas, entre os diferentes processos de preparo. A extração imediata e estratificação a frio úmido, conforme esperado, proporcionou alta porcentagem de emergência das plântulas: 98,0; esse índice baixou para $62,5 \%$, quando os frutos ioram mantidos ao ambiente por 15 dias, e diminuiu ainda mais quando as sementes foram extraídas dos frutos depois de $30,45,60$ e 90 dias, com emergências de $24,5,0,5,7,0$ e 7,5\% respectivamente.

Verifica-se, assim, que a emergência das plântulas manteve-se satisfatória (acima de $60 \%$ ) somente quando a conservaçăo dos frutos ao ambiente se fez até 15 dias. Após esse período, houve queda acentuada de emergência, a índices inaceitáveis, devido à deterioração progressiva da polpa dos frutos, afetando, desse modo, a viabilidade das sementes, a exemplo do que já se verificara, em nossas condições, em sementes de pêssego, caqui e maçã (OJIMA et al., 1976, 1978, e DALL'ORTO et al., 1978).

Como era de esperar, as sementes extraídas de frutos conservados em perfeitas condições, sob refrigeração a $5-10^{\circ} \mathrm{C}$, por 90 dias, e submetidas à estratificação a frio úmido, apresentaram, ainda assim, excelente emergência: 99,0\% (Figura 2). Nesse tratamento e no de frutos conservados na geladeira por 60 dias, os índices de germinação verificados ao final do período de estratificação foram sensivelmente mais altos que os dos demais tratamentos, chegando a atingir 97,5 e $69,0 \%$. Por outro lado, as sementes extraídas de frutos conservados por 60 e 90 dias em frigorífico e semeadas imediatamente sem estratificaçāo, exibiram a emergência significativa de 10,5 e $50,5 \%$ respectivamente, em confronto com a das sementes de frutos recém-colhidos e, igualmente, não estratificadas, que foi de $0,5 \%$. O resultado desses dois tratamentos demonstra que a exigência de frio para a quebra de dormência das sementes foi, pelo menos em parte, satisfeita enquanto elas se encontravam ainda no interior dos frutos conservados em câmara frigorifica. 
QUADRO 3. Porcentagens médias de emergência final das plântulas nos canteiros, de germinação parcial no frigorífico, e dados de emergência transformados em arco seno $\sqrt{\mathrm{P} / 100}$, em 21 processos de preparo de sementes do marmeleiro 'Portugal'

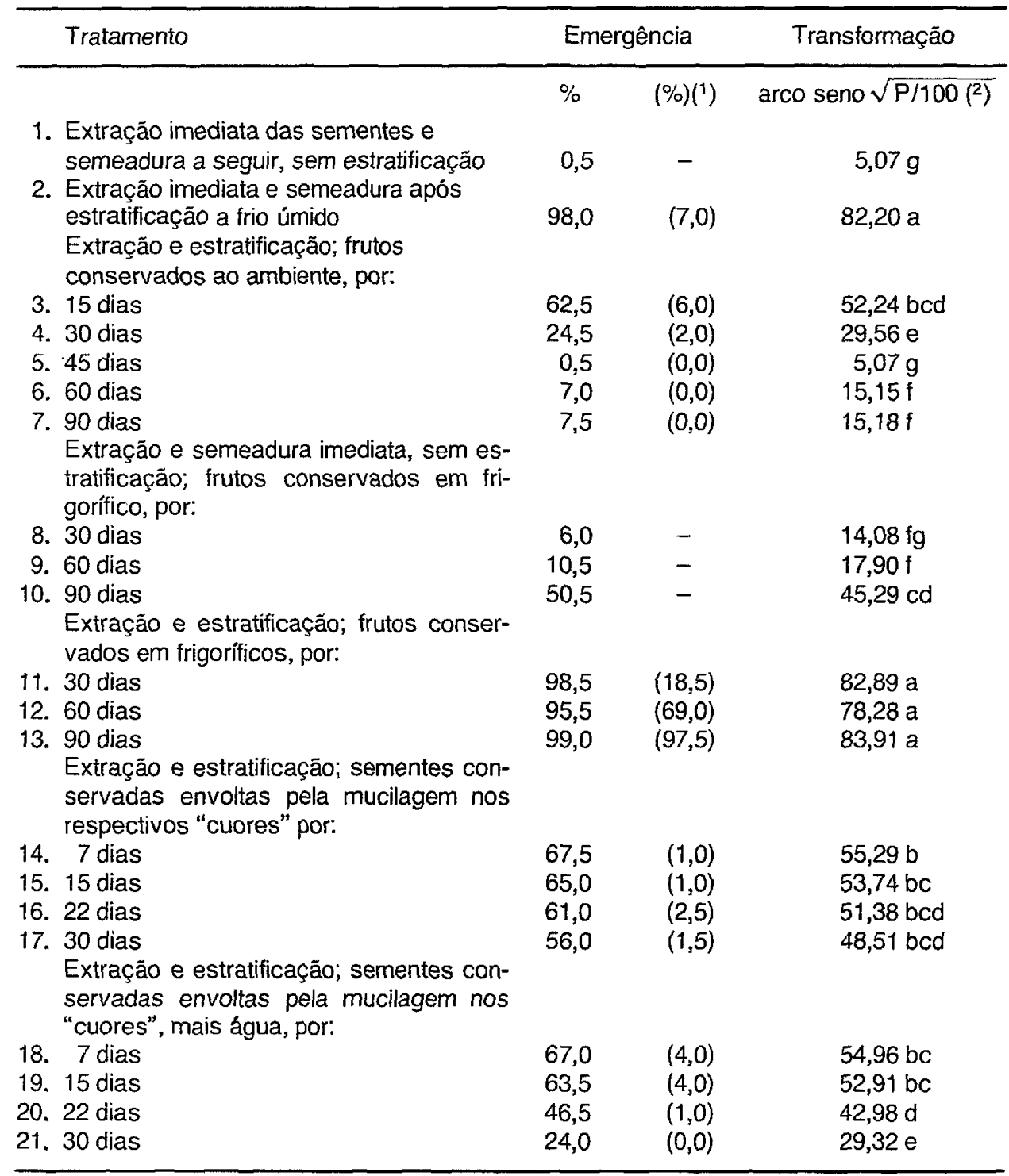

(1) Os números entre parêntesis referem-se às porcentagens iniciais de germinação, nas placas de Petri, ainda no frigorfíico, antes da semeadura nos canteiros.

(2) Entre os tratamentos de preparo de sementes, letras năo comuns indicam diferenças significativas, ao nivel de $5 \%$ pelo teste de Tukey, valores de $s$ (desvio-padrão) $=3,75 ; \mathrm{C} . \mathrm{V}$. (coeficiente de variação) $=$ $8,6 \%, \ominus \triangle$ (diferença significativa) $=9,91$. 


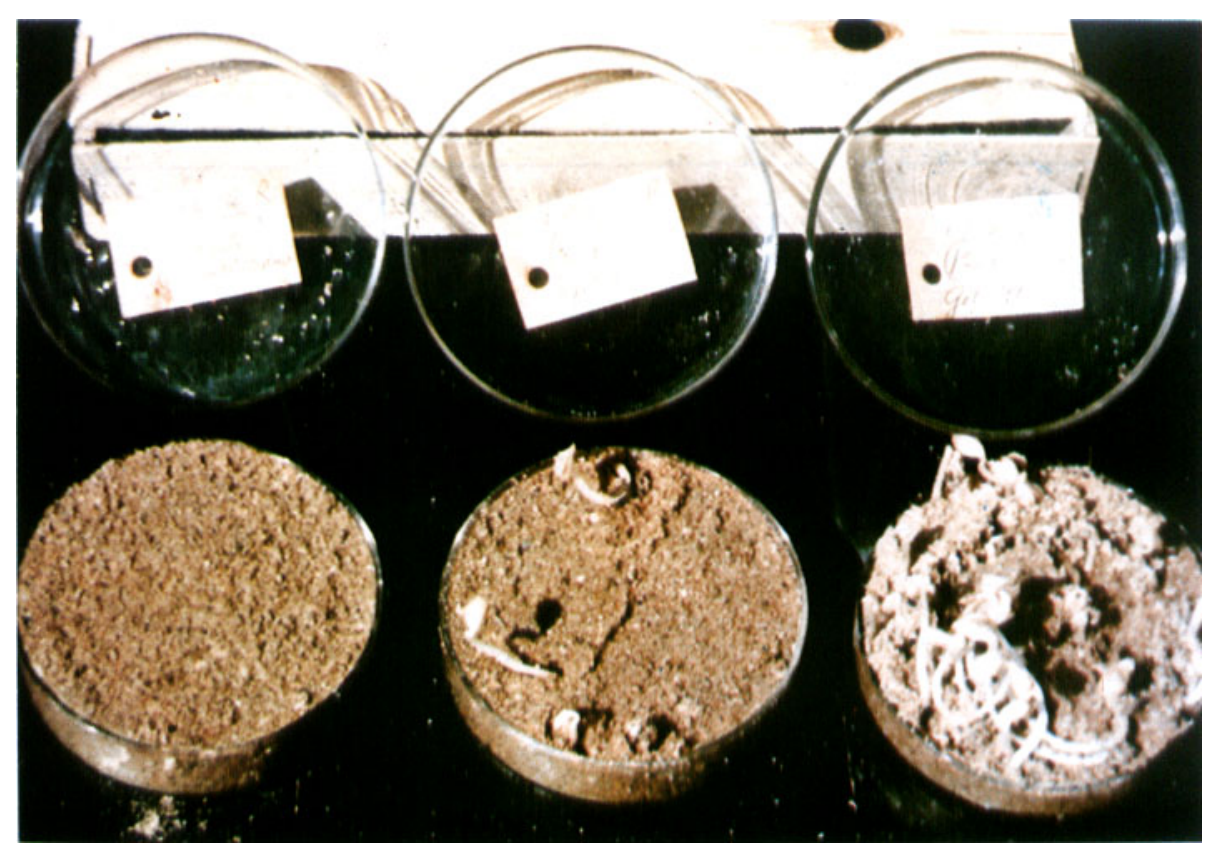

FIGURA 2. Sementes de marmelo em germinação, sob estratificação a frio úmido, em areia; da esquerda para a direita: frutos mantidos ao ambiente por 15 dias e no frigorifico por 30 e 90 dias.

Quanto aos tratamentos envolvendo a conservação das sementes envoltas pela mucilagem, ainda nos respectivos "cuores", se mantidas secas, o índice de emergência apresentou-se como aceitável $(56,0 \%)$ até os 30 dias; se mantidas com água, objetivando maior facilidade na eliminação da mucilagem envoltória das sementes, o que realmente não ocorreu, a emergência manteve-se em nivel adequado $(63,5 \%)$ até os 15 dias. Esse comportamento mais deficiente se deveu à aceleração dos processos de deterioração à medida que a mucilagem se tornava mais gelatinosa e o "cuore" se oxidava.

Em sintese, constatou-se que a demora na extração das sementes e a. falta de estratificação a frio úmido resultaram em baixas porcentagens de germinação. Constatou-se, finalmente, que a viabilidade das sementes de marmelo diminuiu rapidamente, à medida que a polpa dos frutos, a mucilagem e o "cuore", envoltórios naturais das sementes, se deterioraram. 


\section{CONCLUSÕES}

1) A estratificação úmida, à baixa temperatura $\left(5\right.$ a $\left.10^{\circ} \mathrm{C}\right)$, ío indispensável à quebra da dormência fisiológica das sementes de marmelo. A emergência das plantas foi praticamente nula quando as sementes não foram submetidas à estratificação, e ainda bem deficiente, com grande número de plantas anômalas, quando feita por um mês. A completa quebra da dormência deu-se com três meses de estratificação.

2) As sementes do marmelo 'Portugal' apresentaram menor exigência de frio úmido à quebra da dormência do que as do 'Smyrna'.

3) Os três meios de estratificação adotados - algodão, areia e lavagem propiciaram condiçōes satisfatórias e teores adequados de umidade às sementes. O de algodāo constituiu-se no mais asséptico; o de areia, no mais homogêneo e de melhor equilíbrio d'água, e o processo de estratificação por lavagem, o de execução mais trabalhosa.

4) A viabilidade das sementes de marmelo diminuiu rapidamente à medida que a polpa dos frutos, a mucilagem pectinosa e o "cuore", envoltórios naturais das sementes, se deterioraram. Sementes procedentes de frutos deixados ao ambiente tiveram poder germinativo aceitável, quando extraídas aos 15 dias $(62,5 \%)$, caindo drasticamente nos periodos subseqüentes. Sementes com mucilagem, ainda nos "cuores", se mantidas secas, mostraram emergência aceitável até os 30 dias $(56,0 \%)$, porém somente até os 15 , se hidratadas $(63,5 \%)$.

5) A exigência de frio úmido para a quebra de dormência das sementes foi satisfeita em parte, enquanto elas se achavam ainda nos frutos, sob frigorificação; as sementes extraídas de frutos conservados no frigorífico por 90 dias e semeadas sem estratificação apresentaram a significativa emergência de 50,5\%.

\section{SUMMARY}

\section{GERMINATION OF QUINCE SEEDS: MEDIA AND PERIODS OF STRATIFICATION AND PREPARATION PROCESSES}

An experiment was conducted in order to determine the best lenght period and medium (cotton, sand or washing) for the stratification of seeds of quince (Cydonia oblonga Mill.), cultivars Portugal and Smyrna. The following conclusions could be drawn: a) the stratification in moist cold storage was an essential procedure to break the quince seed dormancy; b) the Portugal cultivar, in relation to 'Smyrna', presented lower chilling requirement for a suitable seed germination and seedling emergency; c) the three media utilized provided adequate conditions and satisfactory moisture to the seeds. However, cotton and sand were the best media: the former was 
the most aseptic, and the latter the most homogenous and efficient one. Another experiment was performed to compare seed viability when seeds were prepared by different processes, collected from ripe fruits of the Portugal variety, and kept under various storage conditions. The seeds extracted from ripe fruits up to 15 days after harvest and maintained at laboratory conditions for different periods, showed decreasing emergency indexes, probably due to the detrimental effects of pulp and seed natural coverings deterioration. Seeds extracted from fruits and kept in cold storage for 90 days, sowed immediately or after a period of stratification showed, respectively, medium to high germination percentages.

Index terms: quince, Cydonia oblonga Mill., seeds, media and periods for seed stratification, preparation, germination, emergency, viability.

\section{REFERÊNCIAS BIBLIOGRÁFICAS}

CAMARGO, F.C. \& GONÇALVES, R.D. A cultura do marmeleiro - o combate à entomosporiose. 2.ed. São Paulo, DPV - Secretaria da Agricultura, Indústria e Comércio do Estado de São Paulo, 1943. 18p. (Circular, 13)

DALL'ORTO, F.A.C. Marmeleiro (Cydonia oblonga Mill.) - propagaçāo seminifera, citogenética e radiossensitividade - bases ao melhoramento genético e à obtenção de porta-enxertos. Piracicaba, ESALQ/USP, 1982. 161p. Dissertação (Mestrado)

; OJIMA, M.; BARBOSA, W.; MARTINS, F.P. \& RIGITANO, O. Comportamento do marmeleiro 'MENDOZA INTA-37'. Bragantia, Campinas, 46(1):1-8, 1987.

; RIGITANO, O.; SABINO, J.C \& VEIGA, A.A. Frutificação do marmeleiro 'Provence'. Bragantia, Campinas, 44(1):505-514, 1985a.

; FERRAZ, E.S.B.; IGUE, T.; MAEDA, J.A. \& MARTINS, F.P. Conservação de sementes de marmelo. Bragantia, Campinas, 44(1):347-356, $1985 \mathrm{~b}$.

; RIGITANO, O.; SCARANARI, H.J. \& MARTINS, F.P. Germinação de sementes de maçā. Bragantia, Campinas, 37:83-91, 1978.

OJIMA, M.; DALL'ORTO, F.A.C. \& RIGITANO, O. Germinação de sementes de caqui. Campinas, Instituto Agronômico, 1978. 13p. (Boletim técnico, 51)

Agronômico, 1976. 7p. (Circular, 48)

\& IGUE, T. Sementes de pêssego. Campinas, Instituto 